\title{
Review
}

\section{Role of immune response in Yersinia pestis infection}

\author{
Amedeo Amedei ${ }^{1,2}$, Elena Niccolai ${ }^{1}$, Luigi Marino ${ }^{1}$, Mario M. D’Elios ${ }^{1,2}$ \\ ${ }^{1}$ Department of Internal Medicine, University of Florence, Viale Morgagni 85, 50134 Florence, Italy \\ 2 Department of Biomedicine, Azienda Ospedaliera Universitaria Careggi, Viale Morgagni 85, 50134 Florence, Italy
}

\begin{abstract}
Yersinia pestis (Y. Pestis) is an infamous pathogen causing plague pandemics throughout history and is a selected agent of bioterrorism threatening public health. Y. pestis was first isolated by Alexandre Yersin in 1894 in Hong Kong and in the years to follow from all continents. Plague is enzootic in different rodents and their fleas in Africa, North and South America, and Asia such as Middle/Far East and ex-USSR countries.

Comprehending the multifaceted interaction between $Y$. pestis and the host immune system will enable us design more effective vaccines. Innate immune response and both component (humoral and cellular) of adaptive immune response contribute to host defense against Y.pestis infection, but the bacterium possess different mechanisms to counteract the immune response.

The aims of this review are to analyze the role of immune response versus Yersinia pestis infection and to highlight the various stratagems adopted by $Y$. pestis to escape the immunological defenses.
\end{abstract}

Key words: Yersinia pestis; innate immunity; adaptive immunity.

J Infect Dev Ctries 2011; 5(9):628-639. doi:10.3855/jidc.1999

(Received 30 March 2011 - Accepted 23 May 2011)

Copyright $(\subset 2011$ Amedei et al. This is an open-access article distributed under the Creative Commons Attribution License, which permits unrestricted use, distribution, and reproduction in any medium, provided the original work is properly cited.

\section{Introduction}

Yersinia pestis was first isolated by Alexandre Yersin in 1894 in Hong Kong [1] and the role of fleas in the transmission of plague was subsequently identified [2]. $Y$. pestis has been isolated in all continents, and plague is enzootic in various rodents and their fleas in Africa, North and South America, and Asia such as Middle/Far East and ex-USSR countries $[3,4]$.

Plague is seasonal in most endemic countries with a well defined geographical distribution, which correlates with that of the predominant vectors and rodent reservoirs and their ecology [5].

In 2000 and 2001 more than $95 \%$ of reported human cases were from the African region, including a well documented focus in Madagascar accounting for more than the $41 \%$ of the world's reported cases [6]. Bubonic plague is the predominant form reported worldwide $(80-95 \%$ of cases) [7], with a mortality rate of $10-20 \%$ $[6,8]$.

Increased mortality $(22 \%)$ is seen in a small proportion of patients (10-20\%) who develops systemic Yersinia pestis sepsis without bubo (primary septicaemic plague) [8].
Another rare disease form is primary pulmonary plague which has a mortality rate of $100 \%$ if untreated and more than 50\% with antimicrobial treatment $[7,9]$.

Yersinia pestis is a Gram-negative, non-motile, facultative intracellular bacterium [4] and multilocus sequence typing of housekeeping genes suggests that $Y$. pestis is a clone derived from Yersinia pseudotuberculosis, an enteric pathogen. The annotated genome sequences of five strains of Yersinia pestis, and one strain of Yersinia pseudotuberculosis have been reported, and they show a substantial conservation of DNA sequence and gene complement between $Y$. pestis and $Y$. pseudotuberculosis [10].

Like its cousins, Yersinia pseudotuberculosis and Yersinia enterocolitica, $Y$. pestis is host to the plasmid pCD1. In addition, it also hosts two other plasmids, pPCP1 (also called pPla or pPst) and pMT1 (also called pFra) which are not carried by the other Yersinia species. pFra codes for a phospholipase D that is important for the ability of Yersinia pestis to be transmitted by fleas [11]. pPla codes for a protease, Pla, that activates plasminogen in human hosts and it is a very important virulence factor for pneumonic plague [12]. Together, these plasmids, and a pathogenicity island called HPI, encode several proteins which cause the pathogenesis, which Yersinia pestis is famous for. 
Among other things, these virulence factors are required for bacterial adhesion and injection of proteins into the host cell, invasion of bacteria in the host cell (via a Type III Secretion System), and acquisition and binding of iron that is harvested from red blood cells (via siderophores).

Wild rodent populations are the primary natural reservoirs for $Y$. pestis [13]. In that setting, blood feeding ectoparasites, primarily fleas, transmit the bacilli from one rodent to another and from rodent to humans (bubonic plague) [14].

Recently Yersinia pestis is classified as a bioterrorism agent [15] but it already has a long history as a biowarfare agent [16]. Despite signing the Biological Weapons Convention in 1972, Soviet scientists developed the requisite technology to deploy large quantities of aerosolized Yersinia pestis [16]. Moreover, antibiotic-resistant Yersinia pestis strains are now known to exist [17] and aerosolized would be a formidable and also an intimidating weapon of terror [16].

In humans, the defense against pathogens rests on the early responses mediated by innate immunity and on the delayed responses of the specific immunity. The innate immunity consists of mechanisms, able of a rapid reaction against microbes and it is composed by: physical / chemical barriers (i.e. epithelium and antimicrobial substances); phagocytic cells (i.e. macrophages, neutrophils, and natural killer (NK) cells) and soluble mediators (such as complement proteins, cytokines, chemokines). In detail, the epithelial tissues act as physical and functional barriers to the infectious agents, preventing their access and their growth through the production of natural antimicrobial substances. If these barriers are overcome, microbes face up to professional phagocytes, in particular neutrophils and macrophages, which are able to kill them by their incorporation and digestion in an intracellular compartment called phagolysosome. Macrophages also secrete cytokines and chemokines that stimulate the inflammatory process and lymphocyte responses.

Finally, soluble mediators, such as complement proteins activated by the alternative pathway, are able to eliminate microbes directly by lysis or through their opsonization, so favoring their phagocytosis and subsequent killing.

The exposure to an infectious agent puts into motion also advanced mechanisms, which need more time to be established (four / five days), known as adaptive immune responses. The adaptive (or specific) immunity, mediated by $\mathrm{T}$ and $\mathrm{B}$ lymphocytes, provides a specific protection to the host and a long-lasting immunological memory. Lymphocytes trigger specific immune responses due to the expression of a highly diversified and clonally distributed repertoire of receptors, which interacts with foreign antigens. Any specific response begins in peripheral lymphoid tissues, such as lymph nodes, spleen, and mucosa-associated lymphoid tissues. Here, the naive lymphocytes recognize the antigen presented on the surface of the professional "antigen presenting cells" (APC), in combination with major histocompatibility complex (MHC) molecules. The antigen recognition and the following lymphocytes' activation determines the generation of effector and memory cells. Blymphocytes represent the main defense against extracellular microbes and their toxins, through the release of antibodies in the so-called humoral immunity. Instead, the different $\mathrm{T}$ lymphocytes defend against intracellular microbes, viruses and bacteria, favoring the destruction of the microbes incorporated in the phagocytes or the lysis of infected cells.

Important features of both the $\mathrm{T}$ cell-mediated and the humoral responses are specificity, diversity, memory, specialization, self-limitation, and discrimination of self. Overall, the host is able to eradicate the infections only thanks to the coordinated action of the innate and adaptive immune responses [4].

Anyway, pathogens may develop stratagems to evade the innate and the immune adaptive responses; for example, $Y$. pestis uses several tricks to avoid the immune system control.

This review focuses on the role of the immune response versus Yersinia pestis infection and on the analysis of the various mechanisms adopted by the bacterium to escape the immunological defenses.

\section{Evasion of innate host responses}

Yersinia pestis, through the bite of an infected flea, directly exceeds the skin barrier and reaches the phagocytes at the invasion site. Even if the majority of the bacilli can be eliminated by neutrophils, the facultative intracellular Yersinia pestis infects macrophages, by the recognition of specific surfaceassociated CCR5 molecule [18], where it proliferates and express virulence determinants.

After the acquisition of a phagocytosis resistance profile, it can be delivered from the infected cell to the extracellular space and then, it can propagate into the circulatory system [18]. In this context, Yersinia pestis may evade the host innate immune system both at the early stage of infection and after the release of $Y$. pestis from macrophages. First, the Lipopolysaccharides (LPS) structure, during the passage from gut flea to the 
host temperatures changes, making Yersinia pestis resistant to the serum-mediated lysis and repress the inflammatory response (Figure 1A).

Second, the bacilli escaped from macrophages acquire resistance to phagocytosis and are able to abate the production of pro-inflammatory cytokines and chemokines (Figure1B).

\section{Inhibition of TLR4-mediated activation and resistance to complement-mediated lysis}

LPS are large molecules consisting of a lipid A and a polysaccharide composed of $\mathrm{O}$-antigen, localized in the outer leaflet of Gram-negative bacteria. LPS are recognized by the Toll-like receptor (TLR) 4 whose engagement initiates immune responses [19]. Anyway, the TRL4 signaling is affected by the fatty acid side chains' composition of LPS lipid A. The maximum stimulation is obtained by hexa-acylated lipid A with side chains by 12 to 14 carbons while changes in the number or length of the attached fatty acids decreases the signal strength [20].

Several studies demonstrated that $Y$. pestis synthesizes different forms of LPS depending on hostspecific environmental conditions [21]. For example, Lien's group has demonstrated that $Y$. pestis contain a mixture of stimulatory and non-stimulatory LPS, particularly during the passage from flea to the host [22]. In fact, the temperature differences from the gut flea $\left(26^{\circ} \mathrm{C}\right)$ to the human host $\left(37^{\circ} \mathrm{C}\right)$ favor the synthesis of a tetra-acylated form of LPS, that unlike the typical hexa-acylated LPS, it is not able to induce the TLR4mediated production of pro-inflammatory cytokines (IL-1, IL-6, TNF- $\alpha$, IL-8) [22]. In this way, $Y$. pestis may efficiently block macrophages' activation and secretion of cytokines, which in turn prevents further activation of dendritic cells, essential for the induction of adaptive immune response [22].

In addition, $Y$. pestis has evolved the ability to resist to complement dependent killing in order to survive in the circulation of human host [23-25]. Y. pestis, compared to other Yersinia spp. (i.e. enterocolitica), is able to survive to the complement's action either at $25^{\circ} \mathrm{C}$ or $37^{\circ} \mathrm{C}$ [24]. In enteropathogenic yersiniae, this function is rather mediated by the outer membrane proteins YadA. Otherwise, in $Y$. pestis that do not express YadA, the serum resistance seems to be mediated by LPS and Ail [25]. In fact, Plano and colleagues have widely demonstrated the Ail's mediated protection of $Y$. pestis from in vitro complement dependent killing [25].

\section{Acquirement of phagocytosis resistance}

Phagocytosis is an essential protective mechanism of the innate immunity, mediated by cells able to ingest and destroy microorganisms. In detail, phagocytes ingest the pathogenic microorganisms, and trap them in a phagosome, which then fuses with a lysosome to form a phagolysosome. Within the phagolysosome, enzymes and toxic peroxides digest the pathogen.

As soon as $Y$. pestis overcomes the mucosal barriers, it is phagocytosed by competent cells, and the neutrophils, in the first two days post infection, confine the $Y$. pestis' spread [26]. Anyway, $Y$. pestis, through specific surface-associated molecules, infects the macrophages that appear to be more "compliant" than

Figure 1. Mechanisms of $Y$. pestis' resistance to host innate immunity.

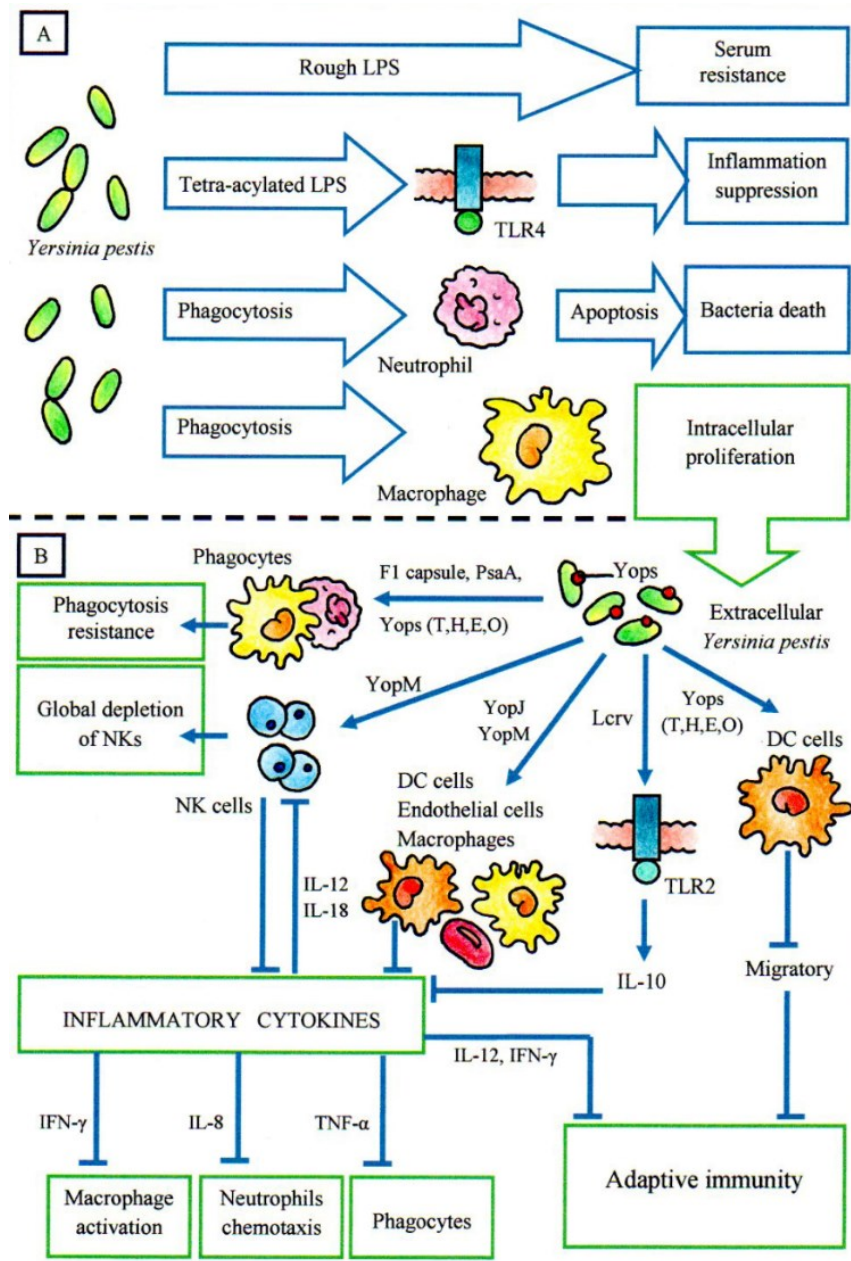

A) Changes in the Lipopolysaccharides' (LPS) structure, during the passage from gut flea to host temperatures, making $Y$. pestis resistant to the serum-mediated lysis. B) The bacteria released from macrophages acquire resistance to phagocytosis and they are able to abate the production of pro-inflammatory cytokines. 
neutrophils, allowing the surviving and the intracellular growth of plague bacilli. This mechanism is indispensable for the plague pathogenesis: it give protection to the bacteria avoiding the contact with other immune components; it provides a replicative niche in which the bacilli can become conditioned to growth at $37^{\circ} \mathrm{C}$; it supplies the time for the expression of virulence determinants that make $Y$. pestis resistant to phagocitosis [27]. Finally, it provides a transport vehicle to the local draining lymph node [28]. After four and five days from infection, the $Y$. pestis bacilli can get away from macrophages spreading into the extracellular space with phagocytosis resistance and causing bacteriemia.

The work of Oyston and collaborators has interestingly shown the possible role of PhoP/PhoQ in mediating the intracellular $Y$. pestis survival in macrophages [29].

After one to four hour of macrophages' infection, the plague bacillum increases the expression of virulence markers such as Yops, F1 antigen, and V antigen [4]. In particular, the expression of F1 antigen permits the formation of a capsule around the bacterium, that protects bacteria from the phagocytosis. F1 seems to interfere at the level of receptor interaction with macrophages and neutrophils working with a different mechanism from that of the type III secretion system (T3SS) [30].

The determinant $\mathrm{pH} 6$ antigen (PsaA) of $Y$. pestis is expressed in response to environmental factor, such as temperature above $34^{\circ} \mathrm{C}$ and low $\mathrm{pH}$, similar to the macrophages phagolysosome [31]. Recently, a study reported that purified PsaA selectively bounds to apolipoprotein $\mathrm{B}(a p o B)$-containing lipoproteins in human plasma [32]. The binding of LDL to the bacterial surface could prevent recognition of the pathogen by the macrophages, favoring the establishment of $Y$. pestis infection [32].

Furthermore, the T3SS genes, located in a $70 \mathrm{~kb}$ virulence plasmid, are a key factor to allow the systemic spreading of plague bacilli. Inside the macrophages, at the temperature of $37^{\circ} \mathrm{C}$, T3SS genes are expressed leading to the formation of an injectisome on the surface of the bacillum [33]. Then, after the evasion from macrophages, $Y$. pestis upon contact with immune cells (macrophages, DCs, and neutrophils), inject in their cytoplasm six different Yersinia outer proteins (Yops; YopE, YopJ/YopP, YopM, YopH, YopT, and YpkA/YopO) thus inhibiting the host immune responses [34].
Negative effects on the innate cellular district

The natural killer cells are a lymphocytes' subset of cells able to kill infected cells by lysis, without the antigens recognition, and to secrete cytokines, in particular IFN- $\gamma$, enhancing the phagocytic activity of macrophages. Evident yet at the second infection day, $Y$. pestis, through the effector YopM, cause a high decrease in the NK cells' number, resulting in a poor secretion of IFN- $\gamma$ that decreases the synthesis of reactive nitrogen intermediates by macrophages [35].

The T3SS proteins YopE, YopT, and YopO, can interfer with the host cell actin regulation of Rho GTPases, inhibiting the $Y$. pestis phagocytosis. Moreover, YopH can inactivate host proteins associated with signaling from the receptor to actin and directly suppress the production of intracellular ROS by phagocytes [36-38]. In addition, the effector protein YopM (an important virulence factor in Yersinia infection in mice) [39] migrates to the nucleus by means of a vesicle-associated pathway [40] thus affecting the expression of genes involved in cell cycle and cell growth, by direct interaction with the protein kinase Clike 2 and ribosomal protein S6 kinase [41].

Yops are also able to inhibit the production of inflammatory cytokines by infected cells; for example, YopPs inhibit the production by macrophages and endothelial cells of TNF- $\alpha$ the most important cytokine to counteract bacterial infection, and IL-8 [42].

An additional $Y$. pestis protein implicated in the inhibition of proinflammatory factors' production is LcrV (low-calcium-response $\mathrm{V}$ or $\mathrm{V}$ antigen), a multifunctional protein involved in contact-induced secretion of Yops' proteins [43]. Once released in the extracellular space, LcrV leads to immunosuppression by a TLR2/CD14- dependent signaling that induces the production of IL-10 and suppresses the TNF- $\alpha$ and IFN$\gamma$ release [44]. The LcrV immunomodulatory properties are demonstrated by the fact that an LcrV mutant strain lacking short amino acid residues (residues 271 to 300) protected animals from $Y$. pestis infection eliciting effector immune responses [45].

Other mechanisms used by $Y$. pestis can disturb the host immune responses; for example, the effectors YopP/YopJ once pumped in the endothelial cells decrease the expression of adhesion molecules (ICAM1 and E-selectin) on endothelial and bronchial epithelial cells, thus inhibiting the recruitment of polimorphonuclear cells to the infection site $[46,47]$. Moreover, LcrV can inhibit the neutrophil chemotaxis both in vivo and in vitro [48].

Furthermore, the suppression of proinflammatory factors' production not only reduces the activation of 
innate immune cells, but also compromises the inflammatory environment that is essential for the adaptive immune response.

\section{Escape of adaptive host immune response}

The adaptive immune responses are carried on by $\mathrm{T}$ and $\mathrm{B}$ cells, activated by the pathogen-associated antigens recognition and the costimuli received by the innate immune cells. It is characterized by antigenspecificity and long-term immunological memory. The plague bacilli are able to reduce the host adaptive immune response influencing the cytokine/chemokine induction (discussed in section 1 and in Figure 1) as well as acting directly by the Yops action on the immune cells implicated in the specific immune responses. In this way, the inactivation of $\mathrm{T}$ cells leading to a reduction of the IFN- $\gamma$ and TNF- $\alpha$ secretion inhibits the innate responses (Figure 2).

\section{Interfering with the antigen presentation of $D C s$}

Dendritic cells are in the interface between innate and adaptive immunity, playing a central role in development of both the immune responses. The main role of DCs is to capture the pathogens in peripheral tissues and to move into secondary lymphoid organs to present the antigen to naive $\mathrm{T}$ lymphocytes. The antigen presentation happens thanks to the ingestion and removal of pathogens within the phagosome followed by its presentation onto the major histocompatibility complex (MHC) molecules. The DCs activate the T cells by an MHC-specific manner [49], providing the required costimulatory signals. Moreover, the DCs contribute to the $\mathrm{T}$ lymphocytes activation by avoiding the suppression of regulatory T cells (CD4 and CD8) by production of IL-6 [50].

Numerous infectious agents are able to prevent the host defenses, for example compromising DC maturation, favoring DCs' apoptosis, or inhibiting cytokines' secretion. While $Y$. enetrocolitica is able to suppress the surface presentation of MHC class II and costimulatory molecules [51], Y. pestis causes the cytoskeleton rearrangement that paralysis DCs' movement [52], by the Yop's injection [53]. This mechanism deeply hamper the DCs' presentation of $Y$. pestis antigens to adaptive cells. The authors found, using Yop $\beta$-lactamase hybrids and fluorescent staining of live cells from plague-infected animals, that $Y$. pestis selects immune cells for injection. In vivo, macrophages, neutrophils and especially dendritic cells were injected most frequently, whereas $\mathrm{B}$ and $\mathrm{T}$ lymphocytes were rarely selected for injection. In this way, $Y$. pestis disables these cell populations to annihilate host immune responses during the infection [53].

\section{Inhibition of the T-cell activation}

Yersinia pestis is also able to affect directly the adaptive immunity by the suppression of $\mathrm{T}$ lymphocytes' activation. The T3SS protein YopH has been previously demonstrated to be able to inhibit the adaptive immune response in vitro [54].

One study have shown that after a transient exposure to $Y$. pseudotuberculosis, $\mathrm{T}$ and $\mathrm{B}$ cells are impaired in their ability to be activated through their antigen receptors; specifically $\mathrm{T}$ cells are inhibited in their ability to produce cytokines (e.g. IL-2), and B cells are unable to upregulate surface expression of the costimulatory molecule, B7.2, in response to antigenic stimulation. The block of lymphocyte activation resulted from the inhibition of early phosphorylation events of the antigen receptor signaling complex. Using $Y$. pseudotuberculosis mutants, the authorsdemonstrated that the inhibitory effect in both $\mathrm{T}$

Figure 2. Mechanisms of $Y$. pestis' resistance to the host adaptive immune response.

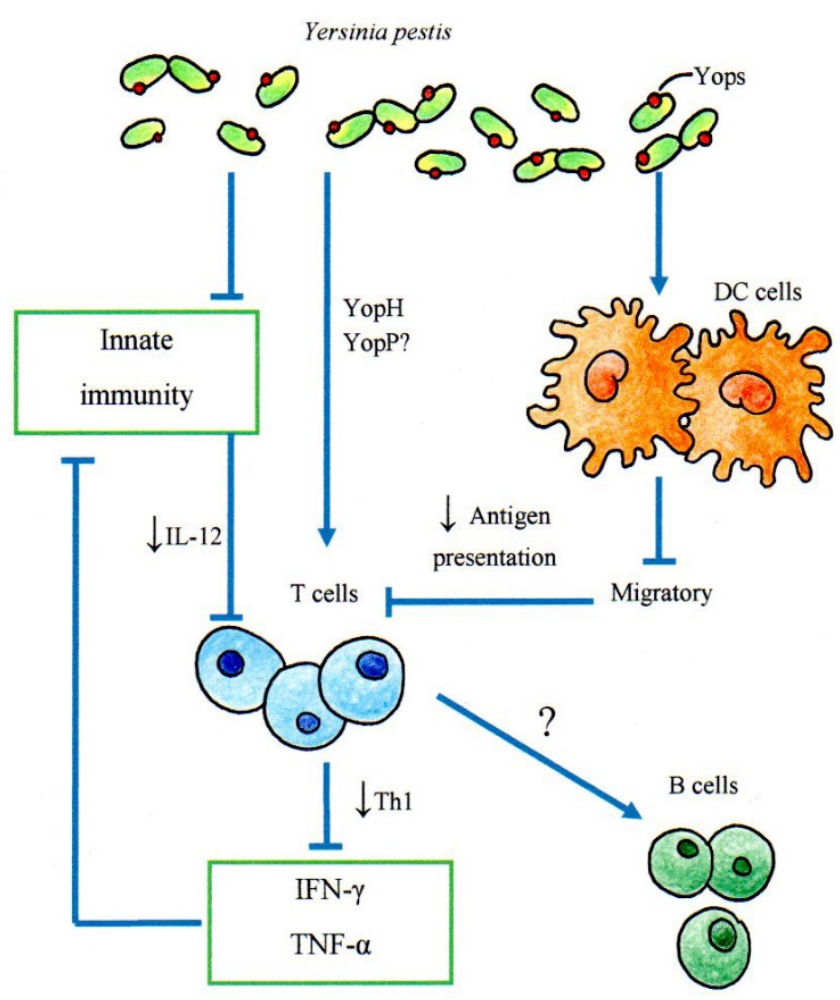

The plague bacilli are able to reduce the host adaptive immune response both influencing the cytokine induction (for example reducing IFN- $\gamma$ and TNF- $\alpha$ ) and acting directly by the Yops action on the immune cells involved in the specific immune responses. 
cells and B cells is dependent on the production of Yop $\mathrm{H}[54]$.

Recently, Alonso and colleagues showed that YopH inhibits the activation of $\mathrm{T}$ lymphocytes by dephosphorylating the Lck tyrosine kinase at Tyr-394, resulting in a complete loss of its catalytic activity [55]. In another study, the same authors demonstrated that prolonged presence of YopH in primary $\mathrm{T}$ cells causes apoptosis, detected by annexin $\mathrm{V}$ binding, mitochondrial breakdown, caspase activation, and internucleosomal fragmentation. YopH also causes cell death when expressed in HeLa cells, and this cell death was inhibited by YopH-specific small molecule inhibitors. Cell death induced by YopH was also prevented by caspase inhibition or co-expression of Bcl-xL. They conclude that YopH not only paralyzes $\mathrm{T}$ cells acutely, but also ensures that they lose the ability to trigger apoptosis by mitochondrial pathway [56].

Moreover, in murine models, the YopP isolated from $Y$. pseudotuberculosis was able to inhibit the expansion of a CD8 T-cell response [57]. However, although this species is closely related to $Y$. pestis, its infection mechanisms can be different as demonstrated by the fact that $Y$. pseudotuberculosis, like $Y$. enterocolitica, usually provokes a chronic infection, while $Y$. pestis causes systemic infections [58]. For example, according to studies on $Y$. enterocolitica, T3SS protein YopJ can induce the programmed cell death of phagocytes, but this determinant is not injected by $Y$. pestis [59]. In addition, the studies about Yersinia pestis and host immune system were mostly focused on T3SS proteins. To better characterize the plague pathogenesis, more specific investigations aimed at understanding and elucidating the interaction between Yersinia pestis and immune systems should be conducted.

\section{Yersinia Pestis-specific immune response}

During $Y$. pestis infection, humoral and cellular immunity cooperate to provide a protection to the host. Antibodies produced by B-lymphocytes can directly neutralize the extracellular bacilli as well as support the cell-mediated immunity by favoring $\mathrm{T}$-cell activation. Together, the cellular immune responses can aid humoral protection by eradicating intracellular $Y$. pestis sources.

The elucidation of the role of $Y$. pestis-specific immune response in the host will give important notions for the characterization of bacterial virulence and will also allow the production of more specific countermeasures.
Antibody-mediated defense against Y. pestis

Numerous proteins belonging to Y. pestis (see Table 1) are able to stimulate the production of specific antibodies by B lymphocytes, both in human and animal models. Moreover, to identify new immunogenic molecules or protective antigens it is possible to profile the antibody host's response, through proteomic technologies [60]. For example, by the antigenome technology, Yang's group has identified at least ten novel immunogenic proteins, such as YPO2090, YPO2091, YPO2102, YPO2112, YPO2118, YPO2131, YPO2190, YPMT1.12c, YPMT1.24c, and YPMT1.75c [61].

It is well known that naïve mice can be immunized by the injection of plague convalescent patients' serum, thus supporting the protective role of the antibody response against the $Y$. pestis infection. Moreover, subunit vaccines, created with the high immunogenic proteins $\mathrm{F} 1$ and LcrV, can supply protection in small animal models, with an antibody mediated mechanism [62-64]. Besides F1, and LcrV, other five proteins (YopD, YpkA, YscF, YadC, and OppA) are able to elicit a protective immune response in the host $[65,66]$.

Although the efficacy of vaccines based on F1/LcrV subunits in small animals, at a Plague Vaccine Workshop sponsored by the Federal Drug Administration's Center for Biologics Evaluation and Research, USAMRIID presented impressive data from a series of primate vaccine trials [67]. The overall

Table 1. Immunogenic proteins of $Y$. pestis.

\begin{tabular}{cc}
\hline Protein & Role \\
\hline LcRV & V antigen \\
YscF & Type III secretion apparatus component \\
YscC & Type III secretion apparatus component \\
YscJ & Type III secretion apparatus component \\
YscO & Type III secretion apparatus component \\
YscP & Type III secretion apparatus component \\
VirG & Targeting protein of the YscC complex \\
YopN & Type III membrane-bound Yop targeting protein \\
TyeA & Type III secretion and targeting protein \\
YopD & Type III targeting component \\
YopH & T3SS effector \\
YopE & T3SS effector \\
YopM & T3SS effector \\
YpkA & T3SS effector \\
YopK & Type III virulence determinant protein \\
OppA & Oligopeptide periplasmic binding protein \\
Pla & Coagulase/fibrinolysin precursor \\
PsaA & pH6 antigen \\
LPS & Lipopolysaccharides \\
YadC & Outer member protein \\
F1 & F1 capsule antigen \\
\hline * &
\end{tabular}


conclusion was that $\mathrm{F} 1 / \mathrm{V}$-based vaccines provide cynomolgus macaques with significant protection against aerosolized $Y p$ challenge, but fail to adequately protect African green monkeys. Presently, we lack a satisfactory explanation for the variable efficacy of F1/V-based vaccines in non-human primates. As such, there is substantial concern that $\mathrm{F} 1 / \mathrm{V}$ vaccines may fail to protect humans against weaponized plague [67]. In other words, antibodies do not seem to effectively protect against pneumonic plague.

Most recently Del Prete and collaborators [68] have described, using in vitro models, the effects of Yersinia pestis recombinant protein $\mathrm{rF} 1, \mathrm{rV}$, and $\mathrm{rF} 1-\mathrm{V}$ on human cells of adaptive immunity especially of B cells.

In detail, using ELISA with native $\mathrm{F} 1$ or $\mathrm{rF} 1$ (recombinant F1) to detect anti-F1 IgG antibodies in $Y$. pestis-primed individuals, they showed that antibody response to $\mathrm{F} 1$ was detectable in patients tested within 20 months from the plague, vanishing thereafter. In the same sera, reactivity to $\mathrm{rF} 1$ was slightly, but consistently, higher than to native F1, suggesting that $\mathrm{rF} 1$ is suitable for diagnostic procedures. In comparison to $\mathrm{rF} 1, \mathrm{rF} 1-\mathrm{V}$ was not equally well recognized by sera of $Y$. pestis-primed subjects. The lower efficiency of $\mathrm{rF} 1-\mathrm{V}$ for antibody binding may be due to poor recognition of its $\mathrm{V}$ portion and to reduction of B-cell epitopes in the F1 portion due to the fusion protein conformation.

\section{Cellular immune defenses to Y. pestis}

Increasingly proofs display the importance of $\mathrm{T}$ cell responses in the struggle against $Y$. pestis infection $[69,70]$.

Type 1 immune reactions, usually implemented toward cancer cells or cells infected by intracellular pathogens, are related to a milieu with cytotoxic functions including enhanced NK, Th1, and $\mathrm{CD}^{+} \mathrm{T}$ cell activities; IFN- $\gamma, \mathrm{TNF}-\alpha$, and nitric oxide synthase 2 , seem to be fundamental also in the fight against pulmonary $Y$. pestis infection. In fact, Philipovskiy and Smiley demonstrated that vaccination with live $Y$. pestis primes $\mathrm{Th} 1$ and $\mathrm{CD} 8^{+} \mathrm{T}$ cells that respond to $Y$. pestis strains lacking the capacity to express F1, LcrV, and all $\mathrm{pCD} 1 / \mathrm{pPCP}$-encoded proteins, suggesting that protective $\mathrm{T}$ cells recognize antigens different from $\mathrm{B}$ cell's antibodies. These observations strongly suggest that development of pneumonic plague vaccines should strive to prime both CD4 and CD8 T cells [71]. Furthermore, the transfer of the $Y$. pestis-primed T cells to naive $\mu$-MT mice protects against fatal intranasal $Y$. pestis challenge, suggesting that cellular immunity, in the absence of antibody, can protect the animal against pulmonary plague [70]. Then, it is clear that vaccines, to be more efficient, should contain different antigens able to elicit both antibody- and T-cell-mediated immunity.

Recently, there has been considerable interest in using transgenic plants to generate compounds for medical and veterinary use [72,73]. The use of a unique vector for robust expression of $Y$. pestis $\mathrm{rF} 1, \mathrm{rV}$, and $\mathrm{rF} 1-\mathrm{V}$ fusion proteins in leaves of Nicotiana benthamiana was described $[74,75]$. The plant-derived Yersinia pestis antigens effectively protected guinea pigs against aerosol challenge with Yersinia pestis at doses $100 \%$ lethal to unvaccinated animals controls [76].

In recent times, we have described the in vitro effects of $Y$. pestis $\mathrm{rF} 1, \mathrm{rV}$, and $\mathrm{rF} 1-\mathrm{V}$ generated in $N$. benthamiana on human cells of the innate and adaptive immunity [68].

This study showed that recombinant plant-derived $\mathrm{rF} 1, \mathrm{rV}$ and $\mathrm{rF} 1-\mathrm{V}$ are TLR2 agonists and importantly, they significantly increase IL-6 and at a lower degree CXCL-8 production by human monocytes, without affecting TNF- $\alpha$ IL-12, IL-10, IL-1 $\beta$, and CXCL10 production.

The data suggest that plant-derived $\mathrm{rF} 1, \mathrm{rV}$ and $\mathrm{rF} 1$ $\mathrm{V}$ are poorly reactogenic on human cells of the innate immunity. No induction of pro-inflammatory cytokines, low induction of IL- 8 and upregulation of IL-6 represent important features of $\mathrm{rF} 1-\mathrm{V}$ in view of its use as candidate vaccine for oral immunization, since no inflammation nor neutrophilia is expected in the gut, while upregulation of IL-6 may be regarded as a promise of prolonged plasma cell survival and antibody response upon vaccination.

The V-antigen (LcrV) was described as the major virulence marker of $Y$. pestis [77]. In mice, $\mathrm{V}$ antigen is an immunomodulator (TNF- $\alpha$ and IFN- $\gamma$ downregulation and IL-10 induction) both in vivo and in vitro [78-84]. Such effects would depend on TLR2 stimulation [85]. In a recent study, the agonistic interaction of $\mathrm{rV}$ with TLR2 was confirmed. Also $\mathrm{rF} 1$ and $\mathrm{rF} 1-\mathrm{V}$ were TLR2 agonists in the same range of relatively high protein concentration. Though $\mathrm{rV}$ was slightly more reactogenic on human monocytes than $\mathrm{rF} 1$, nor up-regulation of IL-10 was detected, nor downregulation of pro-inflammatory cytokines. Whether the lack of $r V$ protein-induced IL-10 increase depend on the source of responder cells (murine vs human) or on recombinant $\mathrm{V}$ proteins (bacterial vs plant), remains unclear. 
In any case, the lack of IL-10 induction in human cells by plant-derived $\mathrm{rV}$ and $\mathrm{rF} 1-\mathrm{V}$ represents a positive feature of these candidates for oral vaccination.

Moreover, the study [65] showed that $\mathrm{rF1}, \mathrm{rV}$, and $\mathrm{rF} 1-\mathrm{V}$ are recognized by memory $\mathrm{T}$-cells and by serum antibodies of a number of patients who recently healed from plague.

In detail, in the three (of the 20 subjects) tested within 20-40 days from disease, no proliferation of $\mathrm{T}$ cells was detectable, though they had already converted to seroposivite for anti-F1 antibodies. Likewise, apart from one donor who showed a poor T-cell response to $\mathrm{F} 1, \mathrm{rF} 1$ and $\mathrm{rF} 1-\mathrm{V}$, but not to $\mathrm{rV}$ antigen, other 5 donors tested after 26 months or more from diagnosis showed no proliferation of their circulating $\mathrm{T}$ cells to native or recombinant $Y$. pestis antigens. Among other $11 Y$. pestis-primed donors tested between 2 and 20 months from diagnosis, 7 showed T-cell proliferation to either native $\mathrm{F} 1$ or $\mathrm{rF} 1$ and $\mathrm{rF} 1-\mathrm{V}$ at the highest concentration $(10 \mu \mathrm{g} / \mathrm{ml})$, but not to lower antigen doses.

In six of of these eleven donors, T-cell proliferation to $\mathrm{rV}$ antigen was also detectable, though lower than to native $\mathrm{F} 1, \mathrm{rF} 1$ or $\mathrm{rF1}-\mathrm{V}$. A significant $\mathrm{T}$-cell proliferation to native $\mathrm{F} 1, \mathrm{rF} 1$, and $\mathrm{rF} 1-\mathrm{V}$, but not to $\mathrm{rV}$ antigen, was observed also in the healthy exposed donor. These data suggest that in the peripheral blood of subjects who got plague, the proportion of $\mathrm{T}$ cells specific for native $\mathrm{F} 1$ or $\mathrm{rF} 1, \mathrm{rV}$, and $\mathrm{rF} 1-\mathrm{V}$ was quite low, and needed at least one month to become detectable in proliferation assays. The need of a relatively high antigen concentration to achieve significant mitogenic indexes argues in favour of this explanation. The data also suggest that in $Y$. pestisprimed donors, the presence of circulating $Y$. pestis antigen-specific $T$ cells is relatively short-term, vanishing after 2 years. Since the analysis of responsiveness by $\mathrm{T}$ cells derived from other sources, such as lymph nodes, was not feasible, the reason why T-cell memory for $Y$. pestis antigens is short lasting in comparison to the memory against other pathogens, remains unanswered.

$\mathrm{T}$-cell responsiveness to $\mathrm{V}$ antigen was never dissociated from that against $\mathrm{F} 1$, but $\mathrm{T}$-cell proliferation to $\mathrm{V}$ was consistently lower than to $\mathrm{F} 1$. The most simple explanation is that during Yersinia pestis' infection, priming of $\mathrm{T}$-cell response to $\mathrm{V}$ antigen was less powerful than to F1. This would have resulted in lower proportions of recirculating $\mathrm{V}$-specific memory $\mathrm{T}$ cells and hence lower proliferative responses in in vitro models.
Strategies for efficient $Y$. pestis vaccination

All the aspects analyzed in previous sections, together with the possibility to elicit antibody responses resembling those of $Y$. pestis-infected subjects and the high protection of guinea pigs from the pulmonary disease, allow to foresee good perspectives for these plant-derived antigens as oral vaccine for prevention of plague.

However, to develop an efficient vaccine, the identification of the different antigens able to elicit a protective $\mathrm{T}$ cell response, is crucial. Then, Yang and collaborators [85] have used in silico analysis and an in vitro IFN- $\gamma$ assay to identify novel $Y$. pestis potential Tcell antigens. In this study, 261 genes from $Y$. pestis were selected on the basis of bioinformatics analysis and previous research results for expression in Escherichia coli BL21(DE3). After purification, 101 proteins were qualified for examination of their abilities to induce the production of IFN- $\gamma$ in mice immunized with live vaccine EV76 by enzyme-linked immunospot assay. Thirty-four proteins were found to stimulate strong T-cell responses. The protective efficiencies for 24 of them were preliminarily evaluated using a mouse plague model.

In addition to LcrV, nine proteins (YPO0606, YPO1914, YPO0612, YPO3119, YPO3047, YPO1377, YPCD1.05c, YPO0420, and YPO3720) may provide partial protection against challenge with a low dose (20 times the $50 \%$ lethal dose $(20 \times$ LD (50)) of Yersinia pestis, but only YPO0606 could partially protect mice from infection with Yersinia pestis at a higher challenge dosage $(200 \times \operatorname{LD}(50))$. These proteins would be the potential components for $Y$. pestis vaccine development.

\section{Future Prospects}

The elucidation of the interactions between Yersinia pestis and host is mandatory for the understanding of the different aspects of the disease's pathogenesis and for the planning and the development of successful countermeasures.

Yersinia pestis is the infamous agent responsible of plague and represent a bioweapon impending public health. To the development of new and more efficient vaccines, it is important to clarify the effector immune responses that the host can implements against the plague's bacilli. Both components (B and $\mathrm{T}$ lymphocytes) of the adaptive immune response contribute to protect the host from Yersinia pestis. However, our current knowledge about the adaptive immune mechanisms elicited during plague infection is still limited. Today, the technological advancement, in 
particular the omics science's field (such as immunomics, genomics, proteomics, metabolomics, ecc.) can offer us new important information for the expansion of more effective and innovative treatments against Yersinia pestis' infection.

\section{Memorial Addendum}

This manuscript is dedicated to the memory of Professor Gianfranco Del Prete, who recently passed away. I and my group personally have to thank the Professor who, with his professional rigor, gave us all the basis for a right and correct scientific research.

In addition, he gave me the passion and dedication in the study of the fascinating galaxy of immunology.

The studies of the Professor Del Prete provided significant and important contributions in various fields of basic and clinical immunology, principally in the different aspects of the immune response pathophysiology; the host adaptive immune response to pathogens; the pathogenetic characteristics of organ-specific autoimmune diseases; and finally the allergy pathogenesis.

Recently, the Professor Del Prete had obtained strong evidence for a potential use of plant-derived antigens as oral vaccine for the prevention of plague and so the correlated comorbidity.

\section{References}

1. Yersin A (1894) La peste bubonique a Hong Kong. Ann Inst Pasteur (Paris) 8: 662-667.

2. Simond P (1898) La propagation de la Peste. Ann Inst Pasteur (Paris) 12: 625.

3. Christie AB, Corbel MJ (1990) Plague and other yersinial diseases. In Smith GR and Easmon CSF, editors. Bacterial Diseases, 8th edition. London: Edward Arnold. 399-421.

4. Perry RD, Fetherston JD (1997) Yersinia pestis--etiologic agent of plague. Clin Microbiology Rev 10: 35-66.

5. Scott S and Duncan C (2001) Biology of plagues: evidence from historical populations. Cambridge: Cambridge University Press.

6. World Health Organization (2003) Human plague in 2000 and 2001.Wkly Epidemiol Rec 78: 130-35.

7. Migliani R (2003) La peste humaine a Madagascar, 45 annees de surveillance de 1957 a 2001. DEA Sante publique et pays en developpement: Universite Pierre et Marie Curie (Paris VI).

8. Inglesby TV, Dennis DT, Henderson DA, Bartlett JG, Ascher MS, Eitzen E, Fine AD, Friedlander AM, Hauer J, Koerner JF, Layton M, McDade J, Osterholm MT, O'Toole T, Parker G, Perl TM, Russell PK, Schoch-Spana M, Tonat K (2000) Plague as a biological weapon: medical and public health management. Working group on civilian biodefense. JAMA 283: 2281-2290.

9. Ratsitorahina M, Chanteau S, Rahalison L, Ratsifasoamanana L, Boisier P (2000) Epidemiological and diagnostic aspects of the outbreak of pneumonic plague in Madagascar. Lancet 355: 111-113.

10. Prentice MB, Rahalison L (2007) Plague. Lancet 369:11961207.

11. Hinnebusch BJ, Rudolph AE, Cherepanov P, Dixon JE, Schwan TG, Forsberg A (2002). Role of Yersinia murine toxin in survival of Yersinia pestis in the midgut of the flea vector. Science 296: 733-755.

12. Lathem WW, Price PA, Miller VL, Goldman WE (2007). A plasminogen-activating protease specifically controls the development of primary pneumonic plague. Science 315509 513.

13. Dennis DT, Gage KL, Gratz N, Poland JD, Tikhomirov E (1999) Plague Manual: Epidemiology, Distribution, Surveillance and Control. Wkly Epidemiol Rec 74: 447.

14. Prentice MB, Rahalison L (2007) Plague. Lancet 369:11961207.

15. Broussard LA (2001) Biological agents: weapons of warfare and bioterrorism. Mol Diagn 6: 323-333.

16. Dennis DT (2005). Plague as a biological weapon. In Fong IW, Alibek K, editors. Bioterrorism and infectious agents: a new dilemma for the 21 st century. Springer Science 37-64.

17. Welch TJ, Fricke WF, McDermott PF, White DG, Rosso ML, Rasko DA, Mammel MK, Eppinger M, Rosovitz MJ, Wagner D, Rahalison L, Leclerc JE, Hinshaw JM, Lindler LE, Cebula TA, Carniel E, Ravel J (2007) Multiple antimicrobial resistance in plague: an emerging public health risk. PLoS ONE 2:e309.

18. Elvin SJ, Williamson ED, Scott JC, Smith JN, Perez De Lema G, Chilla S, Clapham P, Pfeffer K, Schlondorff D, Luckow B (2004) Evolutionary genetics: ambiguous role of CCR5 in Yersinia pestis infection. Nature 430: 417.

19. Takahashi K, Kawai T (2007) Pathogen recognition by Tolllike receptor. Nippon Rinsho 65: 53-57.

20. Miller SI, Ernst RK, Bader MW (2005) LPS, TLR4 and infectious disease diversity. Nat Rev Microbiol 3: 36-46.

21. Rebeil R, Ernst RK, Jarrett CO, Adams KN, Miller SI, Hinnebusch BJ (2006) Characterization of late acyltransferase genes of Yersinia pestis and their role in temperaturedependent lipid A variation. J Bacteriol 188: 1381-1388.

22. Montminy SW, Khan N, McGrath S, Walkowicz MJ, Sharp F, Conlon JE, Fukase K, Kusumoto S, Sweet C, Miyake K, Akira S, Cotter RJ, Goguen JD, Lien E (2006) Virulence factors of Yersinia pestis are overcome by a strong lipopolysaccharide response. Nat Immunol 7: 1066-1073.

23. Une T, Brubaker RR (1984) In vivo comparison of avirulent Vwa- and Pgm- or Pstr phenotypes of yersiniae. Infect Immun 43: 895-900.

24. Anisimov AP, Dentovskaya SV, Titareva GM, Bakhteeva IV, Shaikhutdinova RZ, Balakhonov SV, Lindner B, Kocharova NA, Senchenkova SN, Holst O, Pier GB, Knirel YA (2005) Intraspecies and temperature-dependent variations in susceptibility of Yersinia pestis to the bactericidal action of serum and to polymyxin B. Infect Immun 73: 7324-7331.

25. Bartra SS, Styer KL, O'Bryant DM, Nilles ML, Hinnebusch BJ, Aballay A, Plano GV (2008) Resistance of Yersinia pestis to complementdependent killing is mediated by the Ail outer membrane protein. Infect Immun 76: 612-622.

26. Lukaszewski RA, Kenny DJ, Taylor R, Rees DG, Hartley MG, Oyston PC (2005) Pathogenesis of Yersinia pestis infection in $\mathrm{BALB} / \mathrm{c}$ mice: effects on host macrophages and neutrophils. Infect Immun 73: 7142-7150.

27. Pujol C, Bliska JB (2003) The ability to replicate in macrophages is conserved between Yersinia pestis and Yersinia pseudotuberculosis. Infect Immun 71: 5892-5899.

28. Zhou D, Han Y, Yang R (2006) Molecular and physiological insights into plague transmission, virulence, and etiology. Microbes Infect 8: 273-284. 
29. Oyston PC, Dorrell N, Williams K, Li SR, Green M, Titball RW, Wren BW (2000) The response regulator PhoP is important for survival under conditions of macrophageinduced stress and virulence in Yersinia pestis. Infect Immun 68: 3419-3425.

30. Du Y, Rosqvist R, Forsberg A (2002) Role of fraction 1 antigen of Yersinia pestis in inhibition of phagocytosis. Infect Immun 70: $1453-1460$.

31. Price SB, Freeman MD, Yeh KS (1995) Transcriptional analysis of the Yersinia pestis pH 6 antigen gene. J Bacteriol 177: 5997-6000.

32. Makoveichuk E, Cherepanov P, Lundberg S, Forsberg A, Olivecrona G (2003) pH6 antigen of Yersinia pestis interacts with plasma lipoproteins and cell membranes. J Lipid Res 44: $320-330$

33. Cornelis GR (2002) The Yersinia Ysc-Yop virulence apparatus. Int J Med Microbiol 291: 455-462.

34. Navarro L, Alto NM, Dixon JE (2005) Functions of the Yersinia effector proteins in inhibiting host immune responses. Curr Opin Microbiol 8: 21-27.

35. Kerschen EJ, Cohen DA, Kaplan AM, Straley SC (2004) The plague virulence protein YopM targets the innate immune response by causing a global depletion of NK cells. Infect Immun 72: 4589-4602.

36. Iriarte M, Cornelis GR (1998) YopT, a new Yersinia Yop effector protein, affects the cytoskeleton of host cells. Mol Microbiol 29: 915-929.

37. Rosqvist R, Forsberg A, Rimpilainen M, Bergman T, WolfWatz H (1990) The cytotoxic protein YopE of Yersinia obstructs the primary host defense. Mol Microbiol 4: 657-667.

38. Green SP, Hartland EL, Robins-Browne RM, Phillips WA (1995) Role of YopH in the suppression of tyrosine phosphorylation and respiratory burst activity in murine macrophages infected with Yersinia enterocolitica. J Leukoc Biol 57: 972-977

39. Leung KY, Reisner BS, Straley SC (1990). YopM inhibits platelet aggregation and is necessary for virulence of Yersinia pestis in mice. Infect Immun. 58: 3262-3271.

40. Skrzypek E, Cowan C, Straley SC (1998). Targeting of the Yersinia pestis YopM protein into HeLa cells and intracellular trafficking to the nucleus. Mol Microbiol. 30:1051-1065.

41. McDonald C, Vacratsis PO, Bliska JB, Dixon JE (2003) The yersinia virulence factor YopM forms a novel protein complex with two cellular kinases. J Biol Chem 278: 18514-18523.

42. Boland A, Cornelis GR (1998) Role of YopP in suppression of tumor necrosis factor alpha release by macrophages during Yersinia infection. Infect. Immun. 66: 1878-1884.

43. Pettersson J, Holmstrom A, Hill J, Leary S, Frithz-Lindsten E, von Euler-Matell A, Carlsson E, Titball R, Forsberg A, WolfWatz H (1999) The V-antigen of Yersinia is surface exposed before target cell contact and involved in virulence protein translocation. Mol Microbiol 32: 961-976.

44. Sing A, Rost D, Tvardovskaia N, Roggenkamp A, Wiedemann A, Kirschning CJ, Aepfelbacher M, Heesemann J (2002) Yersinia V-antigen exploits Toll-like receptor 2 and CD14 for interleukin 10-mediated immunosuppression. J Exp Med 196 :1017-1024.

45. Overheim KA, Depaolo RW, Debord KL, Morrin EM, Anderson DM, Green NM, Brubaker RR, Jabri B, Schneewind $\mathrm{O}$ (2005) LcrV plague vaccine with altered immunomodulatory properties. Infect Immun 73: 5152-5159.

46. Denecker G, Totemeyer S, Mota LJ, Troisfontaines P, Lambermont I, Youta C, Stainier I, Ackermann M, Cornelis
GR (2002) Effect of lowand high-virulence Yersinia enterocolitica strains on the inflammatory response of human umbilical vein endothelial cells. Infect Immun 70: 3510-3520.

47. Zhou D, Tong Z, Song Y, Han Y, Pei D, Pang X, Zhai J, Li M, Cui B, Qi Z, Jin L, Dai R, Du Z, Wang J, Guo Z, Huang P, Yang R (2004) Genetics of metabolic variations between Yersinia pestis biovars and the proposal of a new biovar, microtus. J Bacteriol 186: 5147-5152.

48. Welkos S, Friedlander A, McDowell D, Weeks J, Tobery S (1998) V antigen of Yersinia pestis inhibits neutrophil chemotaxis. Microb Pathog 24: 185-196.

49. Banchereau J, Steinman RM (1998). Dendritic cells and the control of immunity. Nature 392: 245-252.

50. Lee HK, Iwasaki A (2007) Innate control of adaptive immunity: dendritic cells and beyond. Semin Immunol 19: 4855.

51. Schoppet, M., A. Bubert, and H. I. Huppertz. 2000. Dendritic cell function is perturbed by Yersinia enterocolitica infection in vitro. Clin. Exp. Immunol. 122: 316-323.

52. Velan, B., E. Bar-Haim, A. Zauberman, E. Mamroud, A. Shafferman, and S. Cohen. 2006. Discordance in the effects of Yersinia pestis on the dendritic cell functions manifested by induction of maturation and paralysis of migration. Infect. Immun. 74:6365-6376

53. Marketon MM, DePaolo RW, DeBord KL, Jabri B, Schneewind O (2005) Plague bacteria target immune cells during infection. Science 309: 1739-1741.

54. Yao T, Mecsas J, Healy JI, Falkow S, Chien Y (1999) Suppression of T and B lymphocyte activation by a Yersinia pseudotuberculosis virulence factor, yopH. J. Exp. Med. 190:1343-1350

55. Alonso A, Bottini N, Bruckner S, Rahmouni S, Williams S, Schoenberger SP, Mustelin T (2004) Lck dephosphorylation at Tyr-394 and inhibition of T-cell antigen receptor signaling by Yersinia phosphatase YopH. J Biol Chem 279: 4922-4928.

56. Bruckner S, Rhamouni S, Tautz L, Denault JB, Alonso A, Becattini B, Salvesen GS, Mustelin T (2005) Yersinia phosphatase induces mitochondrially dependent apoptosis of T cells. J Biol Chem 280: 10388-10394.

57. Trulzsch K, Geginat G, Sporleder T, Ruckdeschel K, Hoffmann R, Heesemann J, Russmann H (2005) Yersinia outer protein $\mathrm{P}$ inhibits CD8 T-cell priming in the mouse infection model. J Immunol 174: 4244- 4251.

58. Brubaker RR (2007) How the structural gene products of Yersinia pestis relate to virulence. Future Microbiol 2: 377385.

59. Zauberman A, Cohen S, Mamroud E, Flashner Y, Tidhar A, Ber R, Elhanany E, Shafferman A, Velan B (2006) Interaction of Yersinia pestis with macrophages: limitations in YopJdependent apoptosis. Infect Immun 74: 3239-3250.

60. Robinson WH (2006) Antigen arrays for antibody profiling. Curr Opin Chem Biol 10: 67-72.

61. Li B, Zhou D, Wang Z, Song Z, Wang H, Li M, Yang R (2008) Antibody profiling in plague patients by protein microarray. Microbes Infect 10: 45-51.

62. Leary SE, Griffin KF, Garmory HS, Williamson ED, Titball RW (1997) Expression of an F1/V fusion protein in attenuated Salmonella typhimurium and protection of mice against plague. Microb Pathog 23: 167-179.

63. Simpson WJ, Thomas RE, Schwan TG (1990) Recombinant capsular antigen (fraction 1) from Yersinia pestis induces a protective antibody response in BALB/c mice. Am J Trop Med Hyg 43: 389-396. 
64. Williamson ED, Vesey PM, Gillhespy KJ, Eley SM, Green M, Titball RW (1999) An IgG1 titre to the F1 and V antigens correlates with protection against plague in the mouse model. Clin Exp Immunol 116: 107-114.

65. Matson JS, Durick KA, Bradley DS, Nilles ML (2005) Immunization of mice with $\mathrm{YscF}$ provides protection from Yersinia pestis infections. BMC Microbiol 5:38.

66. Murphy BS, Wulff CR, Garvy BA, Straley SC (2007) Yersinia pestis YadC: a novel vaccine candidate against plague. Adv Exp Med Biol 603: 400-414.

67. Pitt ML (2004) Non-human primates as a model for pneumonic plague. Animals Models and Correlates of Protection for Plague Vaccines Workshop. Avaiable: http://www.fda.gov/cber/minutes/plague101304t.pdf.

68. Del Prete G, Santi L, Andrianaivoarimanana V, Amedei A, Domarle O, D' Elios MM, Arntzen CJ, Rahalison L, Mason HS (2009) Plant-derived recombinant F1, V, and F1-V fusion antigens of Yersinia pestis activate human cells of the innate and adaptive immune system. Int J Immunopathol Pharmacol 22: 133-143.

69. Elvin SJ, Williamson ED (2004) Stat 4 but not Stat 6 mediated immune mechanisms are essential in protection against plague. Microb Pathog 37: 177-184.

70. Parent MA, Berggren KN, Kummer LW, Wilhelm LB, Szaba FM, Mullarky IK, Smiley ST (2005) Cell-mediated protection against pulmonary Yersinia pestis infection. Infect Immun 73: 7304-7310.

71. Philipovskiy AV, Smiley ST (2007) Vaccination with live Yersinia pestis primes CD4 and CD8 $\mathrm{T}$ cells that synergistically protect against lethal pulmonary $Y$. pestis infection. Infect Immun 75: 878-885.

72. Haq TA, Mason HS, Clements JD, Arntzen CJ (1995) Oral immunization with a recombinant bacterial antigen produced in transgenic plants. Science 268: 714-716.

73. Mason HS, Haq TA, Clements JD, Arntzen CJ (1998) Edible vaccine protects mice against Escherichia coli heat-labile enterotoxin (LT): potatoes expressing a synthetic LT-B gene. Vaccine 16: 1336-1343.

74. Marillonnet S, Thoeringer C, Kandzia R, Klimyuk V, Gleba Y (2005) Systemic Agrobacterium tumefaciens-mediated transfection of viral replicons for efficient transient expression in plants. Nat Biotechnol 23: 718-723.

75. Gleba Y, Klimyuk V, Marillonnet S (2005) Magnifection - a new platform for expressing recombinant vaccines in plants. Vaccine 23: 2042-2048.

76. Santi L, Giritch A, Roy CJ, Marillonnet S, Klimyuk V, Gleba Y, Webb R, Arntzen CJ, Mason HS (2006) Protection conferred by recombinant Yersinia pestis antigens produced by a rapid and highly scalable plant expression system. Proc Natl Acad Sci USA 103: 861-866.

77. Burrows TW (1956) An antigen determining virulence in Pasteurella pestis. Nature 177: 426-427.

78. Brubaker RR (2003) Interleukin-10 and inhibition of innate immunity to Yersiniae: Roles of Yops and LcrV (V antigen). Infect Immun 71: 3673-3681.

79. Sing A, Reithmeier-Rost D, Granfors K, Hill J, Roggenkamp A, Heesemann J (2005) A hypervariable N-terminal region of Yersinia LcrV determines Toll-like receptor 2-mediated IL-10 induction and mouse virulence. Proc Natl Acad Sci USA 102:16049-16054.

80. Covert BA, Spencer JS, Orme IM, Belisle JT (2001) The application of proteomics in defining the $\mathrm{T}$ cell antigens of Mycobacterium tuberculosis. Proteomics. 1: 574-586.

81. Li B, Zhou L, Guo J, Wang X, Ni B, Ke Y, Zhu Z, Guo Z, Yang $R$ (2009) High-throughput identification of new protective antigens from a Yersinia pestis live vaccine by enzyme-linked immunospot assay. Infect Immun. 77: 4356-4361.

82. Sing A, Rost D, Tvardovskaia N, Roggenkamp A, Wiedemann A, Kirschning CJ, Aepfelbacher M, Heesemann J (2002) Yersinia V-antigen exploits Toll-like Receptor 2 and CD14 for interleukin 10-mediated immunosuppression. J Exp Med 196: 1017-1024.

83. Reithmeier-Rost D, Bierschenk S, Filippova N, SchroderBraunstein J, Sing A (2004) Yersinia V antigen induces both TLR homo- and heterotolerance in an IL-10-involving manner. Cell Immunol 231: 63-74.

84. Sing A, Tvardovskaia N, Rost D, Kirschning CJ, Wagner H, Heesemann J (2003) Contribution of Toll-like receptors 2 and 4 in an oral Yersinia enterocolitica mouse infection model. Int J Med Microbiol 293: 341-348.

85. Li B, Zhou L, Guo J, Wang X, Ni B, Ke Y, Zhu Z, Guo Z, Yang $R$ (2009) High-throughput identification of new protective antigens from a Yersinia pestis live vaccine by enzyme-linked immunospot assay. Infect Immun 77: 4356-4361.

\section{Corresponding author}

Amedeo Amedei

Department of Internal Medicine; University of Florence

Viale Morgagni 8550134 Firenze, Italy

Phone: +39.055 .4271495$

Fax: +39.055.4271495

E-mail: aamedei@unifi.it

Conflict of interests: No conflict of interests is declared. 